\title{
Phenotypic Plasticity in Adult Sympathetic Ganglia in vivo: Effects of Deafferentation and Axotomy on the Expression of Vasoactive Intestinal Peptide
}

\author{
H. Hyatt-Sachs, R. C. Schreiber, T. A. Bennett, and R. E. Zigmond \\ Department of Neurosciences, Case Western Reserve University, School of Medicine, Cleveland, Ohio 44106
}

The expression of neurotransmitters/neuromodulators in sympathetic neurons is regulated by anterograde and retrograde mechanisms. We have examined the role of such mechanisms in the regulation of the neuropeptide vasoactive intestinal peptide (VIP). The adult rat superior cervical ganglion (SCG) contains low levels of peptide-like immunoreactivity (IR) and mRNA for VIP. Some VIP-IR nerve processes, but only a few VIP-IR cell bodies, are detectable. Previous evidence demonstrates, however, that after the SCG is placed in organ culture for $48 \mathrm{hr}$, the level of VIP-IR and VIP MRNA and the number of VIP-IR cell bodies and fibers increase considerably. Two of the possible causes for these changes in peptide expression in sympathetic neurons are deafferentation and axotomy, both of which occur when the SCG is placed in culture. To determine the importance of deafferentation, the preganglionic cervical sympathetic trunk was cut and the ganglion left in situ. Forty-eight hours later, VIP-IR increased twofold. A corresponding increase in the number of VIP-IR nerve processes was seen, but there was no detectable change in the number of VIP-IR cell bodies. The content of VIP/PHI mRNA also increased by 1.8-fold. The effect of axotomy on VIP-IR was examined by cutting the postganglionic internal and external carotid nerves and leaving the ganglion in situ. Forty-eight hours later, the level of VIP-IR increased 22-fold, many immunostained neurons were found, and the content of VIP MRNA increased over fivefold. After either deafferentation or axotomy, changes in VIP-IR were accompanied by comparable changes in the related molecule peptide histidine isoleucine amide (PHI)IR. Neuropeptide Y-IR, on the other hand, decreased after deafferentation and increased only twofold after axotomy. The results indicate plasticity in the expression of VIP- and PHI-IR in adult sympathetic neurons in vivo, and suggest that the changes previously seen in organ culture were primarily a response to axotomy.

[Key words: axotomy, cervical sympathetic trunk, decentralization, neuropeptide, peptide histidine isoleucine amide, superior cervical ganglion, vasoactive intestinal peptide]

Received July 6, 1992; revised Oct. 2, 1992; accepted Oct. 20, 1992.

This work was supported in part by U.S. Public Health Service Grant NS17512 and Research Scientist Award MH00162 to R.E.Z. We thank Y. Sun, U. Vaidyanathan, C. Baldwin, T. McKeon, M. Beinfeld, and S. Piszczkiewicz for assistance and Drs. Story Landis and M. Robert Bachoo for comments on the manuscript.

Correspondence should be addressed to Dr. R. E. Zigmond, Department of Neurosciences, Case Western Reserve University, School of Medicine, 2119 Abington Road, Cleveland, OH 44106.

Copyright (C) 1993 Society for Neuroscience $0270-6474 / 93 / 131642-12 \$ 05.00 / 0$
The expression of a number of neurotransmitters and neuromodulators and their rates of biosynthesis are regulated by anterograde and retrograde mechanisms both during development and in the adult. The anterograde mechanisms examined so far primarily involve synaptic activity, while the retrograde mechanisms involve target tissue-derived trophic factors. The beststudied example is the regulation of norepinephrine biosynthesis in sympathetic neurons. More recently, studies have also appeared on the regulation of neuropeptide expression in these neurons, particularly substance $P$, and interesting differences have been proposed between the regulation of norepinephrine and substance P (Kessler et al., 1981; Kessler, 1985a).

The importance of anterograde transsynaptic processes in the regulation of the expression of tyrosine hydroxylase $(\mathrm{TH})$, the enzyme that catalyzes the rate-limiting step in norepinephrine biosynthesis, has been documented in a variety of ways (for reviews, see Thoenen et al., 1979; Black and Patterson, 1980; Zigmond, 1985). For example, deafferentation of the neonatal superior cervical ganglion (SCG) by cutting the preganglionic trunk (i.e., decentralization) has been shown to prevent the normal developmental increase in $\mathrm{TH}$ activity and $\mathrm{TH}$ protein (Black et al., 1971, 1974). Similar results are obtained by administration of nicotinic antagonists, which block synaptic transmission in the SCG (Black and Geen, 1973; Black et al., 1974). On the other hand, chronic depolarization of cultured sympathetic neurons leads to increases in TH expression (Hefti et al., 1982; Wolinsky and Patterson, 1983; Raynaud et al., 1987). TH is also regulated by anterograde transsynaptic processes in the adult SCG. Deafferentation of the adult SCG produces a gradual $25 \%$ decrease in TH activity (Hendry et al., 1973), while electrical stimulation of the preganglionic trunk produces a delayed increase in enzyme activity, whose magnitude depends on the frequency and duration of stimulation (Zigmond and Ben-Ari, 1977; Zigmond and Chalazonitis, 1979; Chalazonitis et al., 1980). The increase in TH activity produced by nerve stimulation is accompanied by comparable increases in TH protein (Zigmond et al., 1980) and TH mRNA (Faucon Biguet et al., 1989) and is largely blocked by nicotinic antagonists (Chalazonitis and Zigmond, 1980; Chalazonitis et al., 1980). Taken together, these and other studies have led to the hypothesis that the biosynthesis of $\mathrm{TH}$ in neonatal and adult sympathetic neurons is stimulated by afferent cholinergic nerve activity.

In contrast, it has been proposed that substance $P$ expression in both neonatal and adult SCG is negatively regulated by afferent nerve activity (Kessler et al., 1981; Kessler and Black, 1982; Adler and Black, 1984; Roach et al., 1987). Decentral- 
ization of the SCG (Kessler and Black, 1982), administration of a nicotinic antagonist (Kessler and Black, 1982), and placing the ganglion in organ culture (Kessler et al., 1981; Adler and Black, 1984) have each been shown to increase the level of substance P-like immunoreactivity (IR). In addition, the increases in the level of substance P-IR and substance P mRNA that normally occur in organ culture are prevented by chronic depolarization of the ganglion with 50-200 $\mu \mathrm{M}$ veratridine (Kessler et al., 1981; Adler and Black, 1984; Roach et al., 1987).

Retrograde signals from sympathetic end-organs constitute a second major class of influences on transmitter expression. The best-studied example of such a signal is the effect of NGF on $\mathrm{TH}$ activity. In addition to its role as a survival factor for neonatal sympathetic neurons, NGF also alters the level of TH relative to other ganglionic proteins. For example, when the concentration of NGF in culture medium is increased from 10 $\mathrm{ng} / \mathrm{ml}$ (required for survival of neonatal sympathetic neurons) to $1000 \mathrm{ng} / \mathrm{ml}$, increases are seen in $\mathrm{TH}$ activity and in the level of TH protein (Hefti et al., 1982). NGF also increases TH activity in the adult SCG in organ culture (Otten and Thoenen, 1976). In vivo in the adult, injection of NGF into one eye produces an increase in TH activity in the ipsilateral SCG (Paravicini et al., 1975). More recently, evidence has been found for target-derived signals that inhibit TH expression. Heart cellconditioned medium has been found to contain leukemia inhibitory factor (LIF), a protein factor that decreases TH activity, TH protein, and TH mRNA in cultured sympathetic neurons (Wolinsky and Patterson, 1983; Nawa et al., 1991). Rao and Landis (1990) have extracted a factor from rat sweat glands, which are innervated by cholinergic sympathetic neurons. This factor, which may be different from LIF, also inhibits TH activity in sympathetic neurons in culture. They have postulated that this sweat gland factor is involved in the inhibition of $\mathrm{TH}$ expression that occurs in normal development when adrenergic neurons contact this particular target tissue (Landis, 1990). These data, and others, indicate that factors released by autonomic target cells (and perhaps other non-neuronal cells) can regulate, both positively and negatively, the level of TH activity.

The effects of NGF and LIF on expression of substance P-IR were different than their effects on the expression of TH. Increasing the concentration of NGF above that required for survival did not increase expression of substance $P$ in cultured sympathetic neurons (Kessler, 1985a). In addition, LIF, which decreases TH expression, increased the expression of substance $P$ and of several other neuropeptides (Nawa and Patterson, 1990; Freidin and Kessler, 1991; Nawa et al., 1991; Rao et al., 1992).

In the present study, we have examined the regulation of the expression of vasoactive intestinal peptide (VIP) in the SCG in vivo. This peptide is of particular interest since it has been found to have a variety of effects on adult SCG, including changes in second messenger levels (e.g., Volle and Patterson, 1982; Audigier et al., 1986), catecholamine biosynthesis (Ip et al., 1985), and muscarinic transmission (e.g., Kawatani et al., 1985) and in embryonic sympathetic neuroblasts on survival and differentiation (e.g., Pincus et al., 1990). VIP is synthesized as part of a larger prepropeptide that includes peptide histidine isoleucine amide (PHI; Tatemoto and Mutt, 1981; Nishizawa et al., 1985), a molecule with which it shares sequence homology (Tatemoto and Mutt, 1981; Nishizawa et al., 1985) and pharmacological actions (e.g., Ip et al., 1985). Normally, the SCG contains a low level of VIP-IR and VIP/PHI mRNA. A number of neural processes exhibiting detectable VIP- or PHI-IR are seen

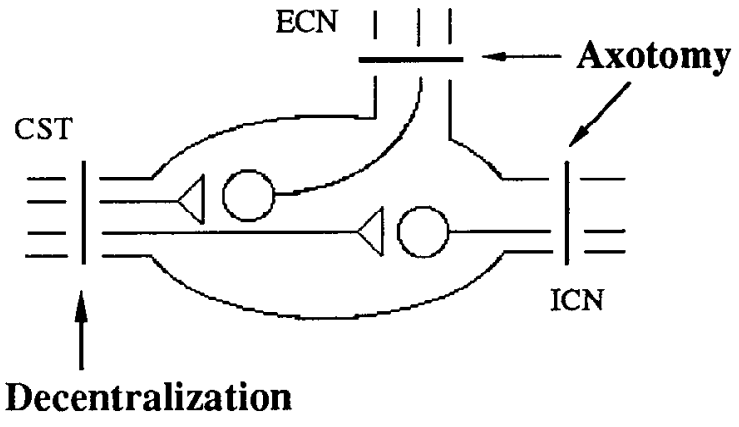

Figure 1. Diagram showing the major afferent input and the major efferent outputs of the rat SCG. CST, cervical sympathetic trunk; ICN, internal carotid nerve; ECN, external carotid nerve. The black bars indicate the sites where transections were made in various experiments.

in the ganglion, but few immunoreactive cell bodies (Hokfelt et al., 1977a; Sasek and Zigmond, 1989; Zigmond et al., 1992). We have recently reported, however, that after the SCG is placed in organ culture for $48 \mathrm{hr}$, many neuronal cell bodies and processes containing VIP- and PHI-IR are seen, the content of VIPIR increases about 30-fold, and there is a large increase in VIP/ PHI mRNA (Zigmond et al., 1992). Placing an SCG in organ culture involves, among other things, interrupting its afferent and efferent connections. To determine the effects of each of these experimental manipulations alone, we have examined the effects of deafferentation and of axotomy of sympathetic neurons in the SCG on VIP expression in vivo.

Some of our findings have been presented to the Society for Neuroscience (Hyatt-Sachs et al., 1990, 1991).

\section{Materials and Methods}

Animals and surgical procedures. Adult male Sprague-Dawley rats (200$250 \mathrm{gm}$; Zivic Miller Laboratories, Allison Park, PA) were anesthetized with chloral hydrate $(770 \mathrm{mg} / \mathrm{kg}$, s.c.), with supplemental use of ether vapors, if necessary. Bilateral decentralization of the SCG was performed by removing a $2 \mathrm{~mm}$ piece from each cervical sympathetic trunk (CST) a few millimeters caudal to the SCG (Fig. 1). Bilateral axotomy of the SCG was performed by transecting the two internal and external carotid nerves (ICN and ECN, respectively) approximately $2 \mathrm{~mm}$ distal to the SCG (Fig. 1). In some animals only the ICN or the ECN was sectioned. Bilateral ptosis was always seen after bilateral transection of the CST or ICN. Other animals were sham operated by exposing, but not sectioning, the appropriate nerve trunks. At various times after the operations, both SCG were removed and examined by radioimmunoassay (RIA), immunohistochemistry, or Northern blot analysis. In addition, ganglia from normal (unoperated) animals werc included as additional controls.

$V I P$ RIA. For RIA, ganglia were removed from animals $1,2,7$, and $42 \mathrm{~d}$ after decentralization or sham operation. The SCG were desheathed, frozen immediately on dry ice, and stored at $-80^{\circ} \mathrm{C}$ until peptides were extracted. Extraction was performed by boiling the ganglia in $2 N$ acetic acid for $20 \mathrm{~min}$. An aliquot of the supernatant was removed for protein determination by the bicinchoninic acid protein assay (Pierce, Rockford, IL), and the remainder was lyophilized. The lyophilized extracts were reconstituted in assay buffer, which contained $0.1 \mathrm{M}$ sodium phosphate (pH 7.3), $0.05 \mathrm{M} \mathrm{NaCl}, 0.1 \% \mathrm{BSA}, 0.1 \%$ Triton X-100, 0.01 $\mathrm{M}$ EDTA, $0.01 \% \mathrm{NaN}_{3}$, and $500 \mathrm{KIU} / \mathrm{ml}$ aprotinin (to inhibit protease activity). VIP was measured by RIA, as previously described (Zigmond et al., 1992), using an antiserum from Peninsula Labs (Belmont, CA; 1:90,000). The data were analyzed using Bcckman's IMMUNOFIT EIA/ RIA analysis software (Beckman Instruments, Fullerton, CA). The sensitivity of the assay (detection limit, approximately $1 \mathrm{pg} /$ tube) allowed the measurement of VIP-IR in individual ganglia. Serial dilutions of the ganglion extracts assayed for VIP-IR yielded a curve that was parallel to the standard curve obtained with synthetic VIP (human/porcine/rat VIP; Bachem Inc., Torrance, CA). Since assay of VIP-IR in ganglion homogenates produced a dilution curve with a slightly altered slope 


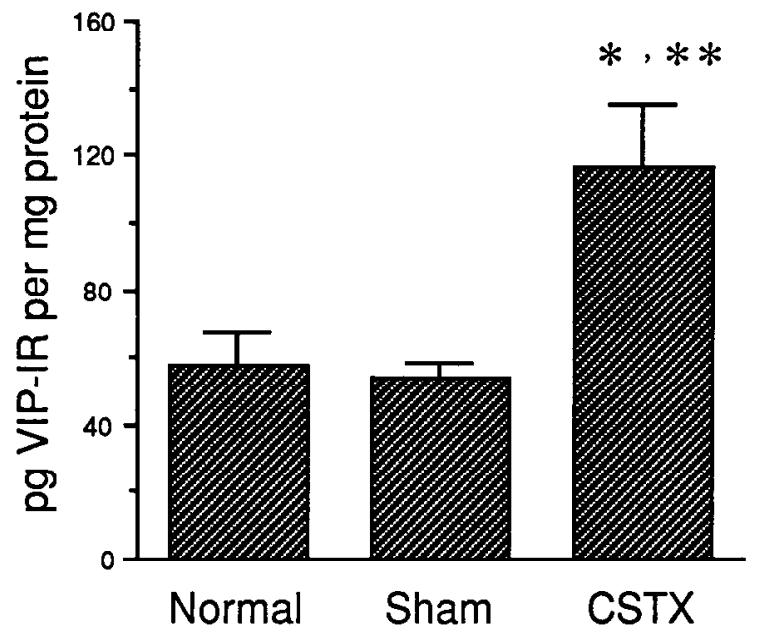

Figure 2. The effect of transection of the CST on VIP-IR in the SCG measured by RIA. Three groups of animals were examined: those with their CST cut $2 \mathrm{~d}$ earlier (CSTX), sham-operated animals (Sham), and unoperated animals (Normal). ${ }^{*}$ indicates a significant difference compared to Sham $(p<0.005)$, and $* *$ indicates a significant difference compared to Normal ( $p<0.01$ ), by Student's $t$ test, two tailed. Each bar represents the mean \pm SEM for 10 ganglia.

compared to that seen with peptide standards, nonhomogenized SCG extracts were used in all experiments. The retention time of the VIPIR in extracts of control SCG was determined in an HPLC system as previously described (Zigmond et al., 1992) and shown to be the same as that of synthetic VIP.

Neuropeptide Y RIA. Neuropeptide Y (NPY)-IR was assayed by RIA using an RIA kit from Peninsula Labs (Peninsula Labs, Belmont, CA). The general procedure was identical to that for the VIP RIA. The assay had a detection limit of about $12 \mathrm{pg} /$ tube.

Peptide immunohistochemistry. Two days, $7 \mathrm{~d}$, and $42 \mathrm{~d}$ after the CST were sectioned and $2 \mathrm{~d}$ after the ICN and ECN were transected, animals were perfused transcardially with either Zamboni's fixative (Stefanini et al., 1967) or $4 \%$ paraformaldehyde. The results with the two fixatives were similar, except that the definition of the TH-IR neurons was sharper when paraformaldehyde was used. In a few cases, the SCG were fixed by immersion in Zamboni's fixative to compare them with previous results on immersion-fixed ganglion explants (Zigmond et al., 1992). SCG from sham-operated rats were processed in the same ways. Following fixation the ganglia were desheathed, cryoprotected in graded concentrations of sucrose, frozen, and sectioned at $10 \mu \mathrm{m}$, as previously described (Sasek and Zigmond, 1989). The tissue was processed for the detection of VIP-IR as outlined by Baldwin et al. (1991) Two rabbit VIP antisera were used with similar results, one, a gift from Dr. J. Allen (University of Cambridge), used at a 1:1000 dilution, and the other, from Peninsula Labs, used at 1:2000. A rabbit PHI antiserum was obtained from J. Fahrenkrug (Bispebjerg Hospital, Copenhagen) and was used at a 1:2000 dilution. The antibodies from Drs. Allen and Fahrenkrug have been characterized previously (Sasek and Zigmond, 1989; Baldwin et al., 1991). Preabsorption of the antiserum with $10 \mu \mathrm{M}$ VIP or omission of the primary antiserum in the immunohistochemical procedure abolished immunostaining in SCG from all experimental groups. Some sections were processed for double labeling using a rabbit VIP antiserum (Peninsula; 1:2000) and a mouse monoclonal antibody to TH (Incstar, Stilwater, MA: 1:500). Other sections were labeled with a guinea pig VIP antiserum (Peninsula; $1: 1000$ ) and with the rabbit PHI antiserum. VIP-IR was detected using either a donkey anti-rabbit or a donkey anti-guinea pig antiserum conjugated to biotin. Secondary antisera had been preabsorbed so as to have minimum cross-reactivity with rat tissue and, in double label studies, with the other primary antiserum (Jackson ImmunoResearch Laboratories, Inc., West Grove, PA), and were subsequently visualized using Texas red conjugated to streptavidin. PHI-IR was detected using a donkey anti-rabbit antiserum, and TH-IR, by a donkey anti-mouse antiserum, in both cases conjugated to FITC. These secondary antisera were also preabsorbed to minimize cross-reactivity (Jackson ImmunoResearch Laboratories, Inc.). For the double labeling experiments, no staining was seen when the primary

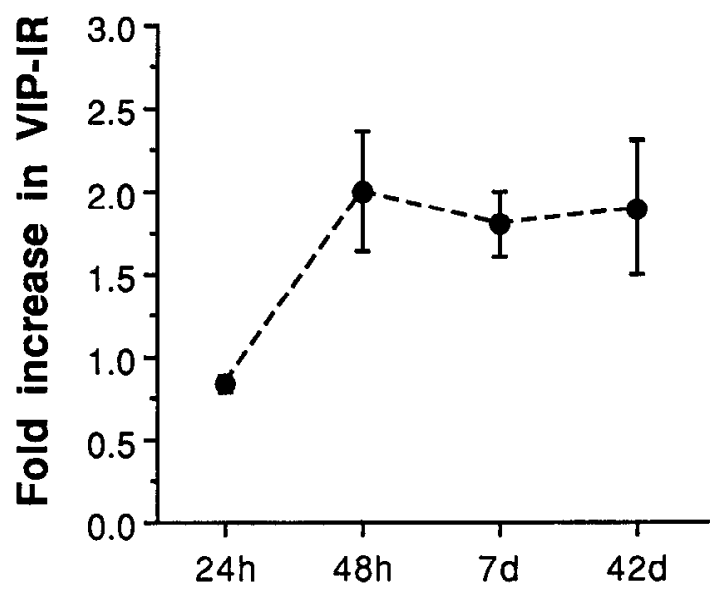

\section{Time after decentralization}

Figure 3. Time course of the change in VIP-IR following decentralization. In separate experiments, ganglia were taken from animals 1,2 , 7 , and $42 \mathrm{~d}$ after bilateral section of the CST or a sham operation. The data are expressed as the mean fold increase in the decentralized ganglia over the sham-operated ganglia ( $N=6-10$ ganglia for each time point).

antisera were omitted or when a secondary antiserum against one species (rabbit or guinea pig) was combined with a primary antiserum against the other.

$R N A$ isolation and Northern blot analysis. Two or $42 \mathrm{~d}$ after deafferentation or $2 \mathrm{~d}$ after axotomy, SCG were removed from rats using sterile instruments, desheathed in a cold sterile balanced salt solution, and frozen immediately in liquid nitrogen. Total RNA was isolated from the ganglia using a guanidine isothiocyanate method (Chomczynski and Sacchi, 1987), separated on $1.2 \%$ formaldchydc-agarose gels, and blotted onto GeneScreen nylon-backed nitrocellulose membrane (New England Nuclear, Boston, MA). The integrity and relative amount of RNA loaded in each lane of the gels were assessed by staining the blots with methylene blue. A ${ }^{32} \mathrm{P}$-labeled RNA probe for VIP/PHI mRNA was made from a 380 base pair fragment of the cDNA for rat VIP/PHI inserted into pSP64 (Segerson et al., 1989; a gift from Dr. J. S. Fink, Harvard Medical School) using a riboprobe kit from Promega. The specific activity of the probe generated was about $10^{8} \mathrm{cpm} / \mu \mathrm{g}$ RNA. Hybridization was performed overnight at $60^{\circ} \mathrm{C}$. Following posthybridization washes, the membranes were wrapped in Saran Wrap and exposed to Kodak XAR-5 film. The probe for VIP/PHI mRNA was stripped from the membranes under high-stringency conditions $\left(0.1 \times \mathrm{SSC}\right.$ and $0.1 \% \mathrm{SDS}$ at $90^{\circ} \mathrm{C}$ for $1 \mathrm{hr}$ ). A ${ }^{32} \mathrm{P}$-labeled DNA probe for glyceraldehyde-3-phosphate-dehydrogenase (GAPDH) mRNA was madc from a cDNA for GAPDH (pGAPDH-13; a gift from Dr. J. M. Blanchard, Université Montpellier II; Fort et al., 1985) by random hexanucleotide priming using the Random Primed DNA Labeling Kit (Boehringer Mannheim). The membranes were rehybridized with the GAPDH probe to compare the relative amounts of RNA loaded in each lane of the gels more quantitatively. The specific activity of the probe generated was about $5 \times 10^{8} \mathrm{cpm} / \mu \mathrm{g}$ DNA, and hybridization of the membranes was performed at $50^{\circ} \mathrm{C}$. The hybridization signals for VIP/PHI and GAPDH mRNA were quantified by densitometric analysis using a Soft Scanning laser densitometer (Biomed Instruments, Fullerton, CA). The fold increases in VIP between experimental and sham-operated control groups were determined by comparing the ratios of the VIP to GAPDH signals between the groups.

\section{Results}

The mean level of VIP-IR \pm SEM measured in three experiments on SCG from nonoperated animals was $8.3 \pm 0.9 \mathrm{pg} /$ ganglion or $74 \pm 7.9 \mathrm{pg} / \mathrm{mg}$ protein ( $N=23$ ganglia).

\section{Changes in VIP-IR in the SCG after decentralization}

Forty-eight hours after the preganglionic CST were sectioned, the level of VIP-IR in the decentralized SCG was twice as high as that found in ganglia from sham-operated or unoperated rats 

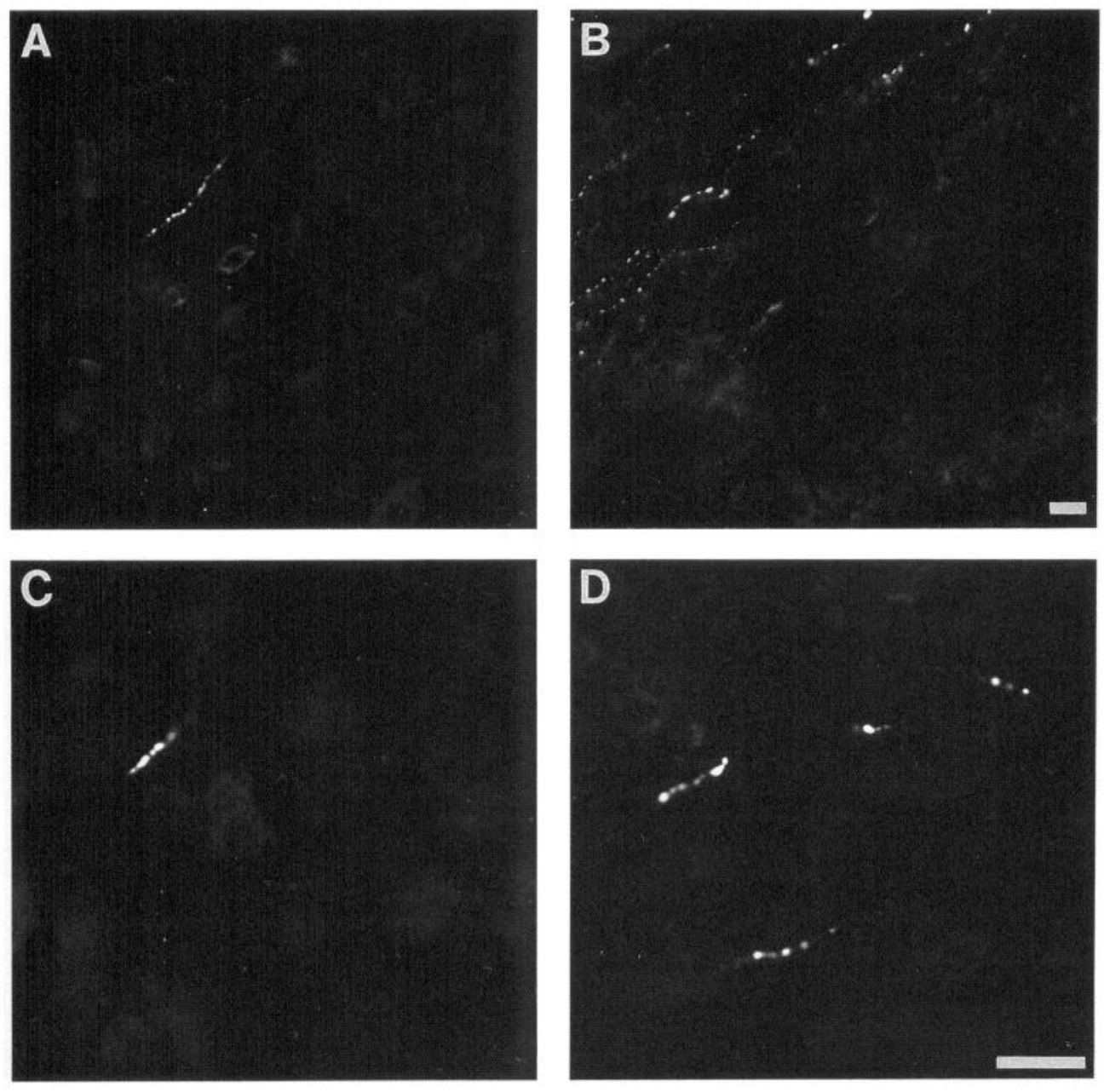

Figure 4. The effect of transecting the CST on VIP- and PHI-IR in the SCG examined by immunohistochemistry. Ganglia from sham-operated animals $(A, C)$ and from animals bilaterally decentralized $7 \mathrm{~d}$ previously $(B, D)$ were examined by fluorescence immunohistochemistry. $A$ and $B$, Changes in VIPIR after decentralization. Scale bar, 25 $\mu \mathrm{m}$. $C$ and $D$, Changes in PHI-IR after decentralization. Scale bar, $25 \mu \mathrm{m}$.
(Fig. 2). The latter two groups did not differ significantly from each other. When the time course of the change in VIP-IR was examined, no change was found during the first $24 \mathrm{hr}$, and the doubling seen at $2 \mathrm{~d}$ was maintained 7 and $42 \mathrm{~d}$ after the operation (Fig. 3). Decentralization produced no change in the protein content of the SCG at any time point examined (data not shown). The effect of decentralization on NPY-IR, another peptide known to be present in the rat SCG (Lundberg et al., 1982; Jarvi et al., 1986), was also examined as an index of the specificity of the VIP response. In contrast to the level of VIPIR, the level of NPY-IR was unchanged $2 \mathrm{~d}$ after decentralization and was decreased by about $30 \% 7 \mathrm{~d}$ after the operation (Table 1).

Ganglia from decentralized and sham-operated animals were examined immunohistochemically for VIP-IR, $7 \mathrm{~d}$ after the surgery. In ganglia from sham-operated animals (Fig. $4 A$ ), single VIP-IR nerve processes were seen scattered throughout the ganglia, but very few immunoreactive neuronal cell bodies were present, as previously reported (Hokfelt et al., 1977a; Sasek and Zigmond, 1989; Zigmond et al., 1992). After decentralization, the density of cell processes immunostained for the peptide was increased throughout the SCG, with no detectable change in the number of immunostained principal neuronal cell bodies (Fig. $4 B)$. Similar results were obtained when ganglia were examined at both earlier ( $2 \mathrm{~d}$ ) and later (42 d) times after decentralization (data not shown). Changes comparable to those seen for VIP-
IR were also found for PHI-IR (Fig. $4 C, D$ ). An attempt was made to determine whether these peptidergic fibers also contained TH-IR; however, this was not possible to do unambiguously, as indicated in the Figure 8 caption.

To determine whether the increase in VIP- and PHI-IR following decentralization was accompanied by an increase in VIP/ PHI mRNA levels, a Northern blot analysis was performed. In ganglia from sham-operated animals, a hybridizing species at 1.7 kilobases, corresponding to the size of VIP/PHI mRNA (Hayakawa et al., 1984; Gozes and Brenneman, 1989; Lamperti et al., 1991), was detected following a long autoradiographic exposure (i.e., 6 d). VIP/PHI mRNA was 1.8 -fold higher in decentralized than in sham-operated ganglia $48 \mathrm{hr}$ after surgery (Fig. 5).

Table 1. The effect of transecting the CST on NPY-IR in the SCG

\begin{tabular}{lll} 
& 2 days & 7 days \\
\hline Sham & $35.3 \pm 2.5$ & $36.4 \pm 2.3$ \\
CSTX & $27.8 \pm 2.6$ & $26.4 \pm 2.0^{*}$
\end{tabular}

Ganglia were taken from animals 2 and $7 \mathrm{~d}$ after bilateral section of the CST (CSTX) or a sham-operation (Sham). The data are expressed as mean NPY content (ng per ganglion) \pm SEM $\left(N=6\right.$ ganglia). ${ }^{*}$ indicates a significant difference from the corresponding sham-operated control using Student's $t$ test, two-tailed ( $p<$ 0.02 ). 


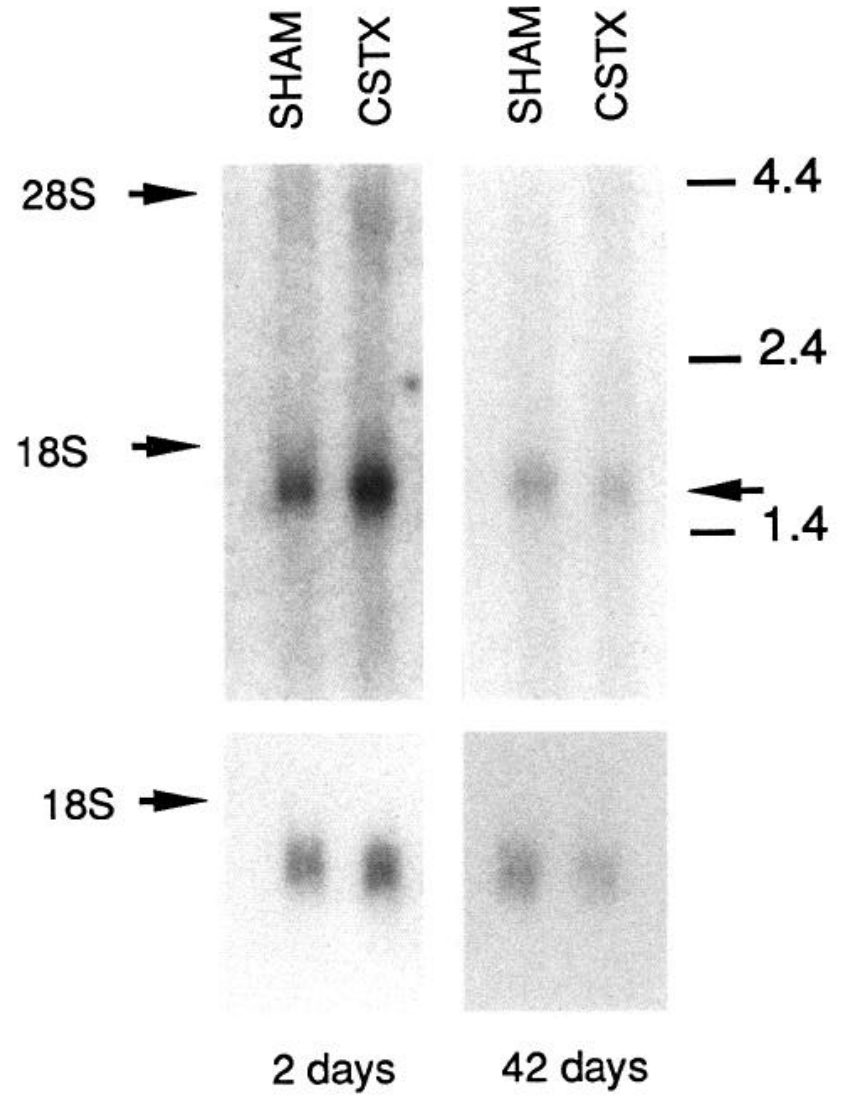

Figure 5. Northern blot analysis of sham-operated or decentralized SCG. RNA was extracted from ganglia $2 \mathrm{~d}$ (left) or $42 \mathrm{~d}$ (right) after surgery and probed with a cRNA for VIP/PHI mRNA (upper panels). Left, Each lane contains RNA from a single SCG. The autoradiogram was exposed for $6 \mathrm{~d}$ at $-80^{\circ} \mathrm{C}$. Right, Each lane contains RNA from two SCG, and the autoradiogram was exposed for $8 \mathrm{~d}$ at $-80^{\circ} \mathrm{C}$. The blots were stripped and hybridized with a cDNA probe for GAPDH (lower panels).

\section{Changes in VIP-IR in SCG after axotomy}

Forty-eight hours after the postganglionic ICN and ECN were lesioned, the content of VIP-IR in the SCG had increased 22fold, compared to ganglia from sham-operated and unoperated animals (Fig. 6). No significant difference was found in the content of VIP-IR in ganglia from the latter two groups (Fig. 6), nor did the protein content of the ganglia differ among the three experimental groups (data not shown). When examined immunohistochemically, previously axotomized SCG contained VIP-IR neuronal cell bodies and processes scattered throughout the ganglion (Fig. 7). Colocalization experiments performed with antisera against both VIP and PHI revealed that the vast majority, if not all, of the labeled cell bodies and processes contained both peptide immunoreactivities (Fig. $8 A, B$ ). In addition, when an antiserum against TH was used here to identify adrenergic sympathetic neurons, almost all of the VIP-IR cells were positive for TH-IR (Fig. $8 C, D$ ). On the other hand, only a subset of the total population of TH-IR neurons exhibited VIP-IR.

When only one of the two major postganglionic nerve trunks, the ICN, was cut, there was also a significant increase in VIPIR (Fig. 9, top), but the increase was considerably smaller (12-

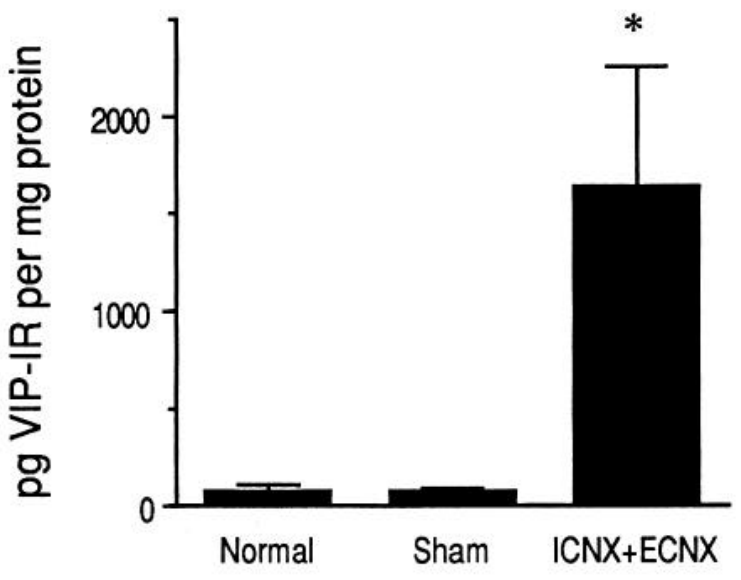

Figure 6. Measurement of the level of VIP-IR in the SCG $48 \mathrm{hr}$ after cutting the ICN and ECN $(I C N X+E C N X) .{ }^{*}$ indicates a significant difference compared to sham and normal $(p<0.03) . N=6$ for each group.

fold) than that seen when both postganglionic trunks were cut (Fig. 6). Interestingly, after the ICN alone was cut, immunostained neuronal cell bodies were not distributed evenly throughout the SCG, but instead were largely restricted to its rostral half (Fig. 10A,B). Some increase in the number of VIPIR nerve processes was seen in both the rostral and caudal portions of the ganglion. Unilateral transection of the ECN alone also increased VIP-IR in vivo (unoperated ganglia, $6.9 \pm 1.4$; contralateral ganglia, $11.1 \pm 9.7$; axotomized ganglia, $56.7 \pm$ $6.0 \mathrm{pg} \mathrm{VIP/ganglion),} \mathrm{and} \mathrm{as} \mathrm{with} \mathrm{cutting} \mathrm{the} \mathrm{ICN,} \mathrm{the} \mathrm{increase}$ in peptide immunoreactivity was smaller than when both trunks were transected.

When the SCG is placed in organ culture all three of its major nerve trunks, the CST, ICN, and ECN, are transected. Therefore, in one group of animals, these trunks were all transected in vivo. Cutting all three nerve trunks produced no further increase in the level of VIP-IR (Fig. 9, top) than that seen when the ICN and ECN alone were cut (Fig. 6). Similarly, cutting the CST and the ICN produced no increase in VIP-IR above that seen when only the ICN was cut (Fig. 9, top). As an index of the specificity of the increase in VIP-IR, NPY-IR was also assayed after lesions were made to the ICN, the CST and ICN, or the CST, ICN, and ECN. NPY-IR was increased two-fold in all three lesioned groups compared to values in ganglia from sham-operated animals (Fig. 9, bottom).

The effect of axotomy on VIP/PHI mRNA was examined by Northern blot analysis (Fig. 11). Forty-eight hours after axotomy, VIP/PHI mRNA increased an average of 5.6-fold in four experiments, compared to that in ganglia from animals that had undergone a sham operation.

\section{Discussion}

Our results demonstrate that large increases in the level of VIPIR in the SCG and in the number of neuronal cell bodies exhibiting VIP- and PHI-IR-previously observed in organ culture (Zigmond et al., 1992)-also occur in vivo after axotomy. In addition, the data suggest that severing postganglionic axons is a major factor causing the increase in VIP-IR in organ culture. If the changes found after organ culture (Zigmond et al., 1992), axotomy, and decentralization are compared, the first two closely resemble each other but differ from the third. First of all, the magnitudes of the increases in the content of VIP-IR are similar 

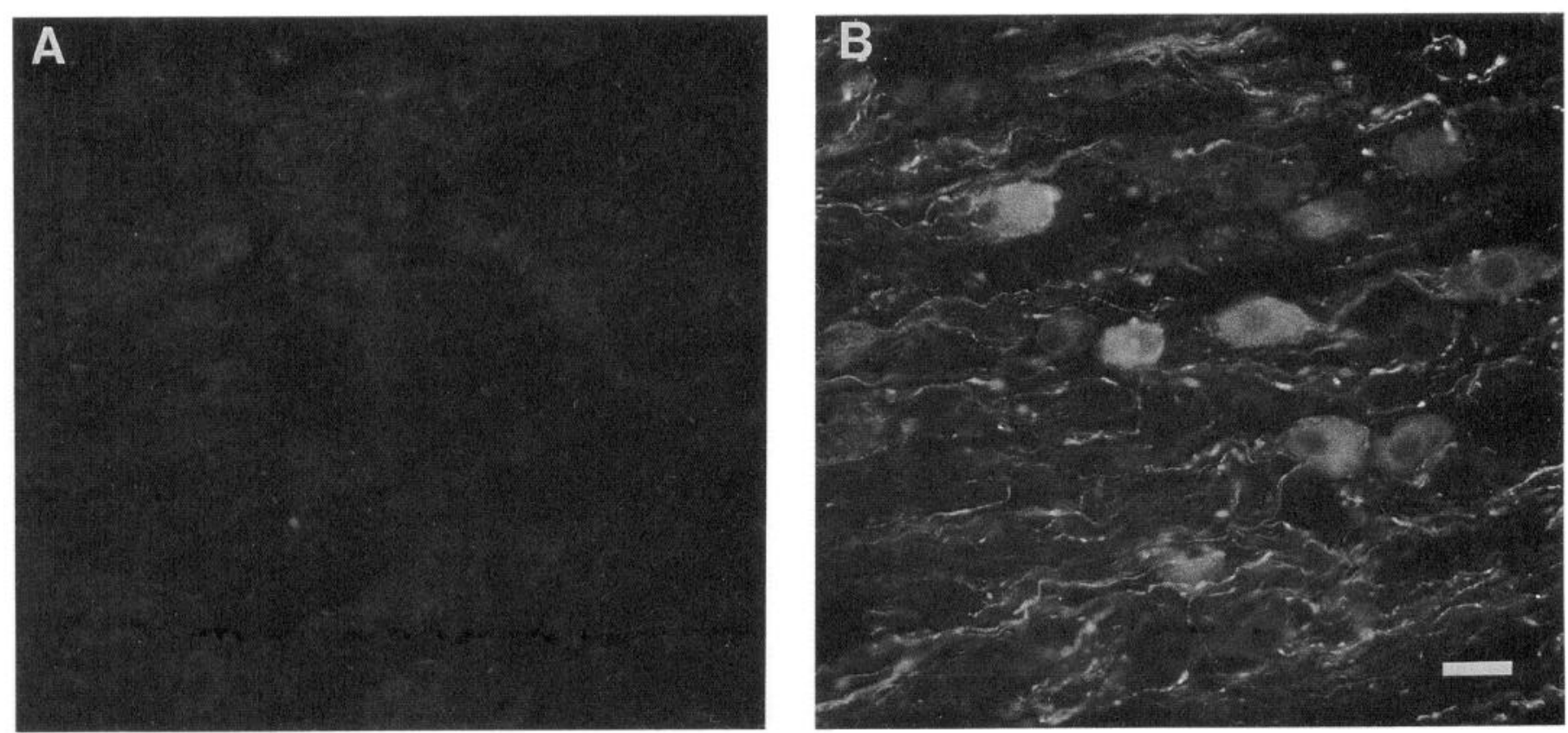

Figure 7. Immunohistochemical examination of VIP-IR in axotomized SCG. $A$, Photomicrograph from a section of SCG of a sham-operated animal. While no VIP-IR processes are found in many fields (such as that shown here), single VIP-IR processes are occasionally seen (e.g., see Fig. $4 A$ ). $B$, Photomicrograph from a section of an axotomized SCG, $48 \mathrm{hr}$ after the surgery. Scale bar, $25 \mu \mathrm{m}$.

after organ culture (31-fold) and after axotomy (22-fold), while the increase after decentralization (2-fold) was an order of magnitude smaller. This difference between decentralization and axotomy is not simply due to a slower rate of change in peptide levels after the former, since the two-fold increase measured at $2 \mathrm{~d}$ was the maximum change seen after this lesion. Second, the change in VIP- and PHI-IR after decentralization appears to be restricted to neural processes, while the changes after organ culture and axotomy involve large increases in the number of immunostained neuronal cell bodies and processes. Third, after organ culture and after axotomy, but not after decentralization, there are large increases in VIP/PHI mRNA, while after decentralization a much smaller increase is seen. In the following discussion, the data on changes in peptide IR after decentralization will be analyzed first, followed by the data on the changes after axotomy.

\section{Localization of the increase in VIP-IR after decentralization}

An increase in VIP- and PHI-IR was detected in the decentralized SCG in nerve processes, with no apparent difference in the number of immunoreactive neuronal cell bodies. A small change in the latter, however, would be hard to detect given the rarity of labeled cell bodies in control ganglia. These immunoreactive processes could represent processes of either intrinsic (e.g., postganglionic sympathetic) or extrinsic (e.g., preganglionic sympathetic, sensory, or parasympathetic) neurons. The fact that no increase in immunostaining was detected in neuronal cell bodies could be interpreted either as indicating the involvement of neurons whose cell bodies are extrinsic to the ganglion or as indicating a greater concentration of VIP-IR in the processes of sympathetic neurons after axotomy than in their cell bodies. The fact that VIP/PHI mRNA increases, though only by 1.8 -fold, supports the idea that the change in VIP expression is at least partly due to changes in neurons in the ganglion.
With regard to possible extrinsic sources for these immunoreactive processes, it seems unlikely that significant numbers of preganglionic sympathetic nerve fibers survive sectioning of the CST, since this lesion causes a $90 \%$ reduction in the number of synaptic profiles within $24 \mathrm{hr}$ (Raisman et al., 1974). However, the IR processes could represent a different afferent input to the ganglion. Two possibilities that exist for such a source are sensory neurons (Helke and Hill, 1988; Kuo et al., 1988) or postganglionic parasympathetic neurons (e.g., the sphenopalatine ganglion; Leblanc et al., 1987). While such VIPergic inputs to the SCG have not as yet been described, there is considerable precedence for a sensory input to prevertebral sympathetic ganglia (Hokfelt et al., 1977b; Dalsgaard et al., 1982; Matthews and Cuello, 1982; Konishi et al., 1985), and in fact, such a pathway containing substance P-IR has been suggested to exist in the rat SCG (Hokfelt et al., 1977b; Gamse et al., 1981). Perhaps, following the extensive deafferentation that occurs in the SCG as a result of decentralization (e.g., Raisman et al., 1974), a sensory or parasympathetic VIPergic pathway sprouts, or alternatively alters its VIP content, leading to an increase in the number of immunostained fibers detectable.

We have previously shown that VIP- and PHI-IR is present in the cell bodies of certain preganglionic sympathetic neurons that project to the SCG (Baldwin et al., 1991). It might therefore have been expected that decentralization of the SCG would lead to decreases in these peptide immunoreactivities in the SCG, rather than to the increases we have found. Nevertheless, the lack of a decrease in VIP and PHI-IR does not disprove the existence of VIPergic or PHIergic preganglionic nerve terminals in the normal SCG. Destruction of these terminals may result in a subsequent increase in VIP in other neuronal elements, thereby masking loss of peptide in the former.

Kessler and Black (1982) investigated the effect of decentralization on substance P-IR in the adult SCG. They reported a $55 \%$ increase by $12 \mathrm{~d}$ after the CST was lesioned. While they 

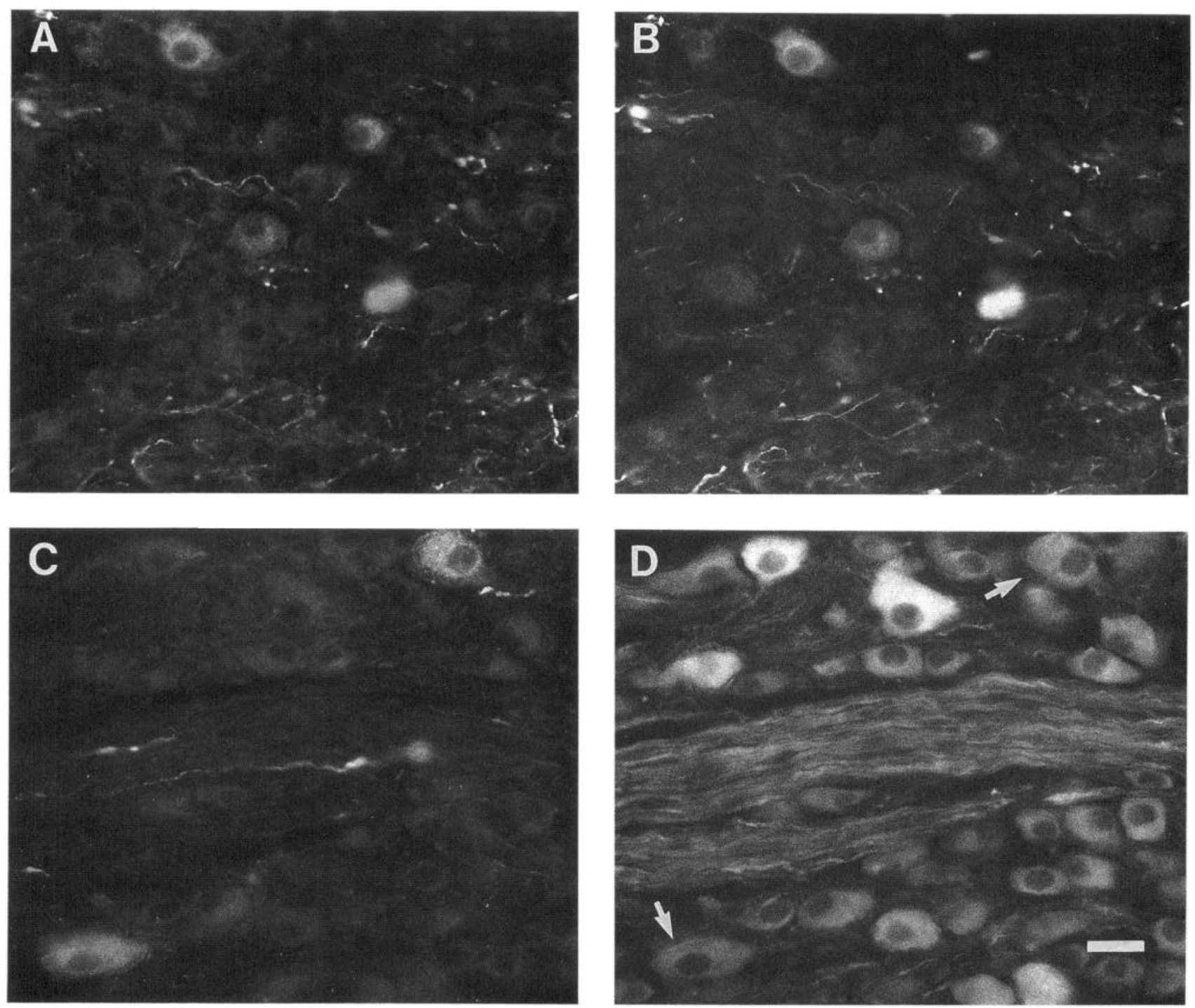

Figure 8. Colocalization of VIP-IR with PHI-IR and TH-IR in axotomized sympathetic neurons. Forty-eight hours after transecting the ICN and ECN, single sections were double labeled using antisera against VIP $(A)$ and PHI $(B)$ or VIP $(C)$ and TH $(D)$. The arrows in $D$ indicate two THIR neuronal cell bodies that show colocalization with VIP-IR. Also in this micrograph, a group of TH-IR fibers can be seen in the middle of the section. The single long VIP-IR fiber seen in the corresponding part of $C$ does not appear to contain TH-IR. These micrographs illustrate, however, the difficulty of determining whether there is colocalization in single VIP-IR fibers located in the vicinity of many TH-IR fibers. Scale bar, $25 \mu \mathrm{m}$.

proposed that the increase in substance P-IR occurred in postganglionic neurons, no supporting immunohistochemical data have been presented. It is striking that substance P-IR and VIPand PHI-IR all increase after decentralization. These changes in peptide levels, however, do not represent a nonspecific peptide response as evidenced by the lack of an increase in NPYIR under the same conditions (Table 1).

\section{Possible stimuli involved in the increase in VIP-IR after decentralization}

The triggering stimulus for the increase in VIP-IR after decentralization remains to be determined. Hypotheses concerning the involvement of afferent nerve activity or cytokines have been proposed previously to explain the increase in substance P-IR seen under the same conditions. While it has been assumed that the increase in substance P-IR occurs in postganglionic neurons, in principle, these same stimuli could act as regulators of peptide levels in extrinsic nerve fibers. Kessler and Black
(1982) proposed that the increase in substance P-IR following decentralization is triggered by the cessation of neural activity in sympathetic neurons (Kessler and Black, 1982). It is worth noting, however, that the firing rate of preganglionic cervical sympathetic neurons in rats under control (e.g., nonstressed) conditions appears to be quite low (see discussion in Zigmond and Chalazonitis, 1979). In fact, the idea that only a small change in firing rates occurs after decentralization has previously been suggested as an explanation for why there is so little change in TH activity in the rat SCG after decentralization (Hendry et al., 1973; Zigmond et al., 1974; Zigmond and Chalazonitis, 1979) even though increasing preganglionic nerve activity is known to increase this enzyme activity (Zigmond and Chalazonitis, 1979). Recently, it has been proposed that the increase in substance $P$ in response to decentralization might be a response to cellular damage, mediated by the release of interleukin$1 \beta$ (IL-1 $\beta$ ) by macrophages (or other non-neuronal cells). While treatment of explant cultures or dissociated cell cultures of SCG 

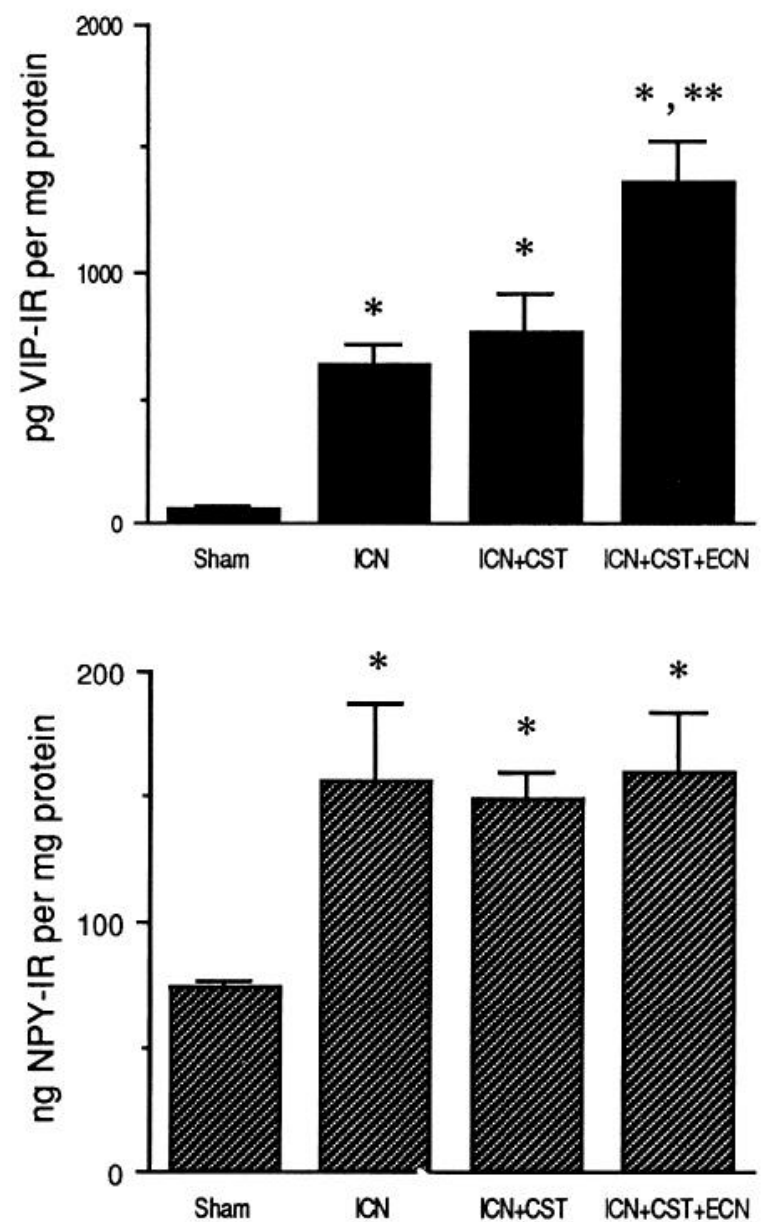

Figure 9. Effect of cutting various combinations of preganglionic and postganglionic nerves on VIP-IR and NPY-IR in the SCG. Ganglia were studied from four groups: (1) sham-operated animals, and animals whose (2) ICN, (3) ICN and CST, and (4) ICN, ECN, and CST were cut. Ganglia were assayed for VIP-IR $48 \mathrm{hr}$ after the surgery. Five to six ganglia were included in each group.

with IL-1 $\beta$ increases substance P-IR in postganglionic neurons (Jonakait and Schotland, 1990; Jonakait et al., 1990; Freidin and Kessler, 1991), no evidence has been presented as yet to connect these changes with those occurring in vivo after decen-
12 45

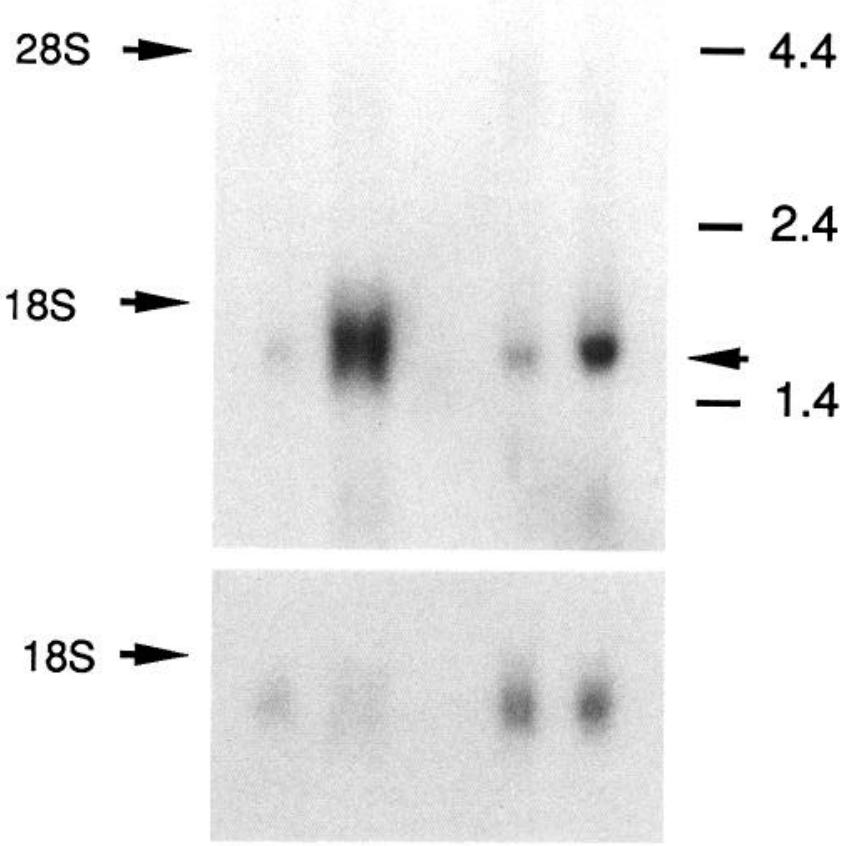

Figure 11. Northern blot analysis of sham-operated and axotomized SCG. Lanes 1 and 2 contain RNA from single SCG $(2.5 \mu \mathrm{g})$, and lanes 4 and 5 contain $8.5 \mu \mathrm{g}$ RNA taken from pools of three ganglia. Lanes 1 and 4 are samples from sham-operated ganglia, and lanes 2 and 5 are from axotomized ganglia. The upper panel contains the blot probed with a cRNA for VIP/PHI mRNA and is from an autoradiogram that had been exposed for $8 \mathrm{~d}$. The blot was then stripped and rehybridized with a cDNA probe for GAPDH mRNA (lower panel). In this experiment, a larger percentage increase in VIP after axotomy was seen in the sample in lane 2 than in the one in lane 5.

tralization. Furthermore, given the time course for the change in VIP-IR after decentralization, if IL- $1 \beta$ were involved, it would either have to be released over a prolonged period (e.g., several weeks) or produce a very long-lasting effect on ganglionic VIPIR. Finally, although it is not at present known whether the level of IL- $1 \beta$ differs in the vicinity of the SCG after decentralization or axotomy, it is important to note that, as discussed
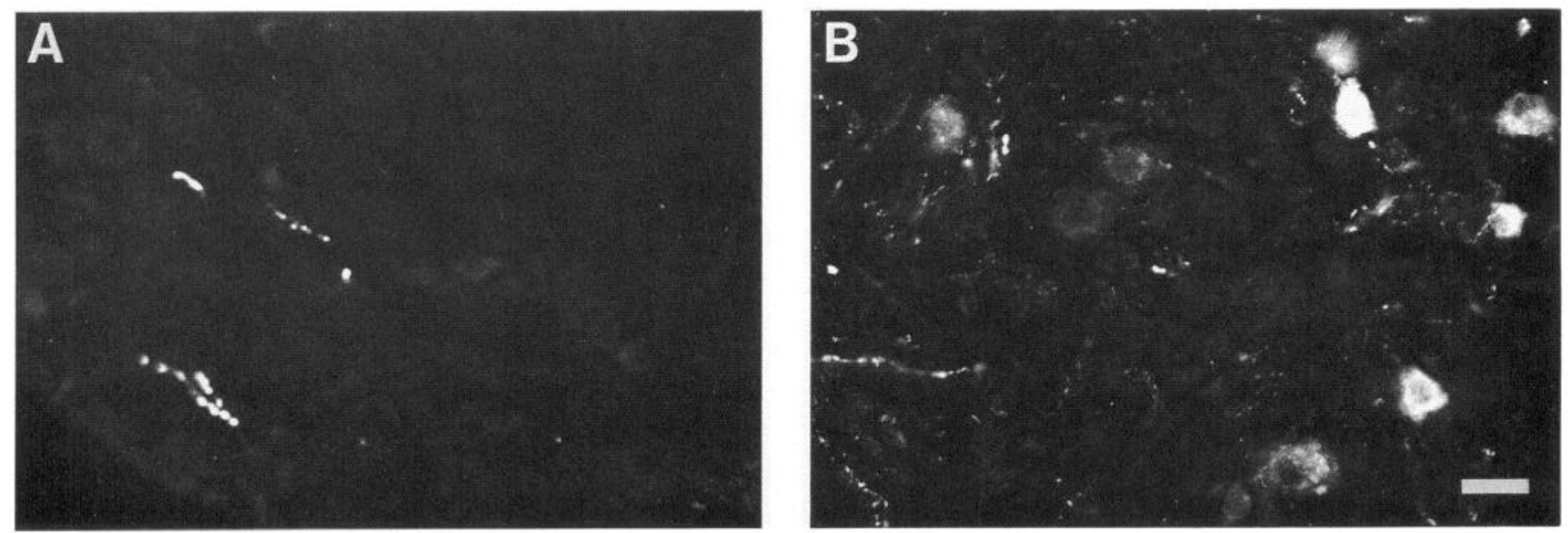

Figure 10. Distribution of VIP-IR neuronal cell bodies after the ICN alone is cut. Forty-eight hours after the ICN was cut, sections were processed for VIP-IR and photomicrographs were made in two areas of the ganglion: the area near the point where the CST exits from the ganglion $(A)$ and the area near the opposite pole of the ganglion were the ICN exits $(B)$. Scale bar, $25 \mu \mathrm{m}$. 
above, large quantitative and, perhaps, qualitative differences exist in VIP-IR after these two types of nerve damage.

Decentralization may alter the level of VIP-IR via changes in trophic relationships in the ganglion. Sympathetic denervation of the iris leads to an increase in substance P-IR in sensory neurons in the tissue. This change, which could represent sprouting of sensory fibers or an increase in peptide content with no change in fiber number, is hypothesized to result from the increased availability of NGF due to the absence of sympathetic nerve endings that normally take up this factor (Kessler, 1985b). Similarly, cutting the preganglionic sympathetic inputs to the SCG might increase the availability of a trophic factor, produced by postganglionic neurons, that can act on sympathetic preganglionic, sensory, or parasympathetic neurons. Alternately, preganglionic ncurons may normally rclcasc a factor(s) that inhibits the levels of certain neuropeptides in the SCG.

\section{Possible stimuli involved in the increase in VIP-IR after axotomy}

Since cutting the preganglionic input did not mimic the effects of placing the SCG in organ culture, we examined the effects of cutting the major postganglionic trunks of the SCG, the ICN and the ECN. Unlike decentralization, axotomy results in a clear increase in the number of neuronal cell bodies in the SCG with detectable VIP- and PHI-IR. That these immunostained cell bodies are adrenergic principal neurons is indicated by their size and their TH-IR. Retrograde tracing studies suggest that the ICN and ECN contain the axons of at least $35 \%$ and $45 \%$, respectively, of the principal neurons in the $\mathrm{SCG}$, and that few, if any, neurons project into both trunks (Bowers and Zigmond, 1979). In view of these findings, our data indicate that only a portion of the neurons that would be expected to be axotomized in our experiments exhibit detectable VIP- and PHI-IR after the surgery. Similarly, only a minority of the neurons in the SCG exhibited VIP-IR when the ganglion was placed in organ culture (Zigmond et al., 1992). It is not known whether a greater number of immunoreactive neurons would be detectable at later times after the surgery; however, it is possible that only a distinct subpopulation of neurons in the SCG exhibit detectable VIPIR after axotomy.

Our data do not directly address the question of whether the peptide response is limited only to neurons that are axotomized. The distribution of VIP-IR cell bodies after only one of the two postganglionic trunks was cut, however, supports this idea. In an earlier study, the distribution within the SCG of cell bodies whose axons project into the ICN or ECN were examined (Bowers and Zigmond, 1979). The distribution of VIP- and PHI-IR neuronal cell bodies after the ICN alone was cut (Fig. 3) is very similar to the distribution previously shown for all neurons whose axons project into the ICN (Bowers and Zigmond, 1979). These findings suggest that VIP-IR is present in axotomized neurons; however, they do not rule out the possibility that nearby, but intact, neurons are affected.

Traditionally, the increase in the level of a peptide in a neuronal cell body after its axon has been ligated, crushed, or cut has been interpreted as due to a blockade of anterograde transport of the molecules from the cell body, with no change in the amount of peptide the neurons make (e.g., Hokfelt et al., 1980). However, the large increase in VIP/PHI mRNA that occurred in this study, concurrent with the increase in VIP-IR, suggests that axotomy also produces a change in peptide expression. A similar change in both VIP-IR and VIP/PHI mRNA was seen when ganglia were placed in organ culture (Zigmond et al., 1992). Also, the relatively small (approximately two-fold) changes after axotomy or organ culture in the level of NPY-IR, a peptide that is detectable in about half of the neurons in the normal SCG (Lundberg et al., 1982; Jarvi et al., 1986), suggests that decreased transport probably only accounts for a relatively small part of the change in VIP- and PHI-IR.

Three basic types of triggering stimuli can be proposed to explain the increase in VIP-IR following sympathetic axotomy. One is a stimulus arising from the general trauma produced by the surgery. The second is a stimulatory factor released from the site of nerve damage. The third is the removal of an inhibitory target-derived differentiation factor resulting from the disruption of the connection between the neurons and their targets. A major role for general tissue trauma seems unlikely in view of the fact that no detectable changes were found in VIP-IR between sharr-axotomized and unoperated SCG. We cannot rule out, on the other hand, a role for a factor(s) released as a direct result of nerve section. Preliminary data, however, indicate that application of colchicine to intact sympathetic axons produces similar effects on VIP expression as does actually cutting of the axons (M. R. Bachoo and R. E. Zigmond, unpublished observations). The latter result suggests that interruption of communication between a neuron and its target, without severing its axon, leads also to an increase in VIP-IR.

There is considerable precedence for an important role played by the loss of target-derived trophic factors in producing changes after sympathetic neurons are axotomized. $\mathrm{Nja}$ and Purves (1978), for example, showed that both chromatolysis and the depression of ganglionic transmission (see below) that occur after axotomy arc greatly reduced if NGF is applied directly to the ganglion. Similarly, in sensory neurons, the decrease in substance $\mathrm{P}$ expression produced by sectioning peripheral nerve processes can be prevented by administration of NGF (Fitzgerald et al., 1989; Wong and Oblinger, 1991). While we have not as yet tested the effects of NGF after axotomy in vivo, we have found that NGF does not reverse the increase in VIP seen in organ culture (Zigmond et al., 1992). It seems quite possible that in sympathetic nerves, as in sensory nerves, some of the changes that follow axotomy can be reversed by NGF, while others cannot (Wong and Oblinger, 1991). We are currently exploring the possibility that sympathetic end-organs contain a factor(s), other than NGF, that normally suppresses VIP expression in those sympathetic neurons that innervate these tissues.

\section{Comparison of the regulation of VIP-IR in axotomized adrenergic sympathetic neurons and developing cholinergic sympathetic neurons}

While few sympathetic neurons in the adult SCG normally exhibit VIP- or PHI-IR, a small group of neurons in the stellate and lumbar ganglia do in both the cat (Lundberg et al., 1979) and rat (Landis, 1990). Some of these neurons innervate sweat glands. During pustnatal development in the rat, the sympathetic neurons innervating sweat glands begin to express VIPIR shortly after they have contacted their end-organs (Landis et al., 1988). It has been proposed that this phenotypic change is caused by the action of a target-derived, retrogradely transported, differentiation factor present in the sweat glands (Rao and Landis, 1990; Schotzinger and Landis, 1990). This developmental phenomenon appears to differ from the one described in the present article in two ways. First of all, adult sympathetic 
neurons in the SCG begin to express VIP-IR when their connections to their targets are severed, while neonatal neurons innervating the foot pad express VIP-IR subsequent to contacting their target. Second, the developmental increase in VIPIR in sympathetic neurons is accompanied by an increase in ChAT (Leblanc and Landis, 1986) and a substantial decrease in TH in the same neurons (Landis et al., 1988). Previously published data suggest that the increases in VIP-IR in the adult reported here are not accompanied by changes in ChAT activity (Hendry, 1976; Johnson et al., 1980; Nagata et al., 1989) or dramatic changes in TH (Hendry, 1976; Kessler and Black, 1979; Gilad et al., 1980). Interestingly, Nawa and Patterson (1990) have reported the presence in heart cell-conditioned medium of a factor that increases VIP-IR in sympathetic neurons but does not alter their adrenergic versus cholinergic phenotypc. While the production of a stimulatory factor like LIF by target tissues would be unlikely to have relevance to the increases in expression of VIP and PHI seen after transecting postganglionic nerves, the same factor produced by non-neuronal cells in the ganglion following axotomy could play a key role in these processes (Sun et al., 1992).

\section{Possible complexity in interpreting effects of sympathetic nerve lesions}

The effects of sectioning the CST are generally assumed to result from deafferentation of neurons in the SCG, and the effects of sectioning the ICN and ECN, from axotomy of those neurons. These interpretations, however, do not take into account certain anatomical complexities in the system. For example, a small number of principal neurons in the caudal part of the SCG (less than $1 \%$ of the total neurons in the ganglion) project into the CST, and these neurons are axotomized when the CST is sectioned (Bowers and 7igmond, 1979). It seems unlikely, however, that these few axotomized neurons could totally account for the increase in VIP-IR after the CST is cut, because the increase is detected in VIP-IR nerve processes, rather than cell bodies, in contrast to what is seen when the postganglionic trunks are cut. Furthermore, the VIP-IR processes are distributed throughout the ganglion rather than being restricted to its most caudal part where the cell bodies of the population of neurons projecting into the CST are concentrated. Nevertheless, preliminary evidence using in situ hybridization with an oligonucleotide probe complementary to part of the VIP/PHI mRNA indicates that a few cell bodies in the most caudal part of the ganglia do begin to accumulate VIP/PHI mRNA after decentralization (R. Mohney and R. E. Zigmond, unpublished observations).

A second possible complication arises from the obscrvation that sectioning of the ICN and ECN leads to a gradual reduction in synaptic transmission in the SCG (Matthews and Nelson, 1975; Purves, 1975). This physiological change is accompanied by the detachment of preganglionic nerve endings from the chromatolytic postganglionic neurons (Matthews and Nelson, 1975; Purves, 1975). Matthews and Nelson (1975) reported such anatomical and physiological changes within $24 \mathrm{hr}$ after axotomy, while Purves (1975) did not detect them until after $72 \mathrm{hr}$. Such changes in afferent input could clearly complicate the interpretation of experiments on axotomized sympathetic neurons and, in fact, in axotomized neurons in other neural systems (e.g., Blinzinger and Kreutzberg, 1968). Nevertheless, the clear differences between the effects of axotomy on VIP-IR and those of decentralization make it unlikely that changes in afferent input play a major role in this preparation.

\section{Regulation of NPY-IR after decentralization and axotomy}

The level of NPY-IR decreased about 30\% 1 week after decentralization. Recent studies have shown that the level of NPY mRNA in the SCG decreases after decentralization and increases after reserpine administration (Hanze et al., 1991; Schalling et al., 1991). In addition, NPY mRNA levels increase after electrical preganglionic stimulation of human lumbar sympathetic ganglia (Schalling et al., 1989). Thus, it is likely that NPY expression, like that of TH (Faucon Biguet et al., 1989), is stimulated by preganglionic nerve activity. The level of NPY-IR increased approximately twofold after axotomy, an effect similar to that previously reported after explantation (Zigmond et al., 1992). It is somewhat puzzling that there was no difference in the magnitude of the increase when either both the ICN and ECN or only the ICN were transected. Determination of the extent to which this twofold change represents increased biosynthesis of NPY-IR or increased peptide accumulation, due to decreased axonal transport and release of the peptide by axotomized neurons, must await further experimentation.

\section{Possible physiological significance of changes in VIP-IR after axotomy}

In contrast to its effect on VIP and PHI-IR, axotomy has previously been reported to produce a reduction in $\mathrm{TH}$ activity (Cheah and Geffen, 1973). Based on this finding and others regarding motor and sensory neurons, it has been hypothesized that axotomy shifts the priorities of neurons from synaptic transmission to regeneration (e.g., Matthews and Raisman, 1972; Grafstein and McQuarrie, 1978). Along this line, axotomy is known to produce chromatolysis in sympathetic neurons, a set of changes in the cytoplasmic organization of these neurons related to subsequent regeneration (Matthews and Raisman, 1972; Gabella, 1976). In addition, there is an increase in expression of certain cytoskeletal proteins, such as $\mathrm{T} \alpha_{1}$-tubulin and actin, that are necessary for axonal regeneration (Koo et al., 1988; Mathew and Miller, 1990). Whether the increase in VIPand PHI-IR are also related to the maintenance and regeneration of axotomized neurons remains to be determined.

\section{References}

Adler JE, Black IB (1984) Plasticity of substance $P$ in mature and aged sympathetic neurons in culture. Science 225:1499-1500.

Audigier S, Barberis C, Jard S (1986) Vasoactive intestinal polypeptide increases inositol phospholipid breakdown in the rat superior cervical ganglion. Brain Res 376:363-367.

Baldwin C, Sasek CA, Zigmond RE (1991) Evidence that some preganglionic sympathetic neurons in the rat contain vasoactive intestinal peptide- or peptide histidine isoleucine amide-like immunoreactivities. Neuroscience 40:175-184.

Black IB, Geen SC (1973) Trans-synaptic regulation of adrenergic neuron development: inhibition by ganglionic blockade. Brain Res 63:291-302.

Black IB, Patterson PH (1980) Developmental regulation of neurotransmitter phenotype. Curr Top Dev Biol 15:27-40.

Black IB, Hendry IA, Iversen LL (1971) Trans-synaptic regulation of growth and development of adrenergic neurons in a mouse sympathetic ganglion. Brain Res 34:229-240.

Black IB, Joh HT, Reis DJ (1974) Accumulation of tyrosine hydroxylase molecules during growth and development of the superior cervical ganglion. Brain Kes 75:133-144.

Blinzinger K, Kreutzberg G (1968) Displacement of synaptic terminals from regenerating motorneurons by microglial cells. Z Zellforsch Mikrosk Anat 85:145-157.

Bowers CW, Zigmond RE (1979) Localization of neurons in the rat 
superior cervical ganglion that project into different postganglionic trunks. J Comp Neurol 185:381-392.

Chalazonitis A, Zigmond RE (1980) Effects of synaptic and antidromic stimulation on tyrosine hydroxylase activity in the rat superior cervical ganglion. J Physiol (Lond) 300:525-538.

Chalazonitis A, Rice PJ, Zigmond RE (1980) Increased ganglionic tyrosine hydroxylase and dopamine- $\beta$-hydroxylase activities following preganglionic nerve stimulation: role of nicotinic receptors. J Pharmacol Exp Ther 213:139-143.

Cheah TB, Geffen LB (1973) Effects of axonal injury on norepinephrine, tyrosine hydroxylase and monoamine oxidase levels in sympathetic ganglia. J Neurobiol 4:443-452.

Chomczynski P, Sacchi N (1987) Single-step method of RNA isolation by acid guanidinium thiocyanate-phenol-chloroform extraction. Anal Biochem 162:156-159.

Dalsgaard C-J, Hokfelt T, Elfvin L-G, Skirboll L, Emson P (1982) Substance P-containing primary sensory neurons projecting to the inferior mesenteric ganglion: evidence from combined retrograde tracing and immunohistochemistry. Neuroscience 7:647-654.

Faucon Biguet N, Rittenhouse AR, Mallet J, Zigmond RE (1989) Preganglionic nerve stimulation increases mRNA levels of tyrosine hydroxylase in the rat superior cervical ganglion. Neurosci Lett 104: 189-194.

Fitzgerald M, Wall PD, Goedert M, Emson PC (1989) Nerve growth factor counteracts the neurophysiological and neurochemical effects of chronic sciatic nerve section. Brain Res 332:131-141.

Fort P, Marty L, Piechaczyk M, el Sabrouty S, Dani C, Jeanteur P, Blanchard JM (1985) Various rat adult tissues express only one major mRNA species from the glyccraldehyde-3-phosphate-dehydrogenase multigenic family. Nucleic Acids Res 13:1431-1442.

Freidin M, Kessler JA (1991) Cytokine regulation of substance P expression in sympathetic neurons. Proc Natl Acad Sci USA 88:32003203.

Gabella G (1976) Structure of the autonomic nervous system, pp 7982. London: Chapman and Hall.

Gamse R, Wax A, Zigmond RE, Leeman SE (1981) Immunoreactive substance $P$ in sympathetic ganglia: distribution and sensitivity towards capsaicin. Neuroscience 6:437-441.

Gilad GM, Gagnon C, Kopin IJ (1980) Protein carboxymethylase activity in the rat superior cervical ganglion during development and after axonal injury. Brain Res 183:393-402.

Gozes I, Brenneman DE (1989) VIP: molecular biology and neurobiological function. Mol Neurobiol 3:201-236.

Grafstein B, McQuarrie IG (1978) Roel of the nerve cell body in axonal regeneration. In: Neuronal plasticity (Cotman CW, ed), pp 155-195. New York: Raven.

Hanze J, Kummer W, Haass M, Lang RE (1991) Neuropeptide Y mRNA regulation in rat sympathetic ganglia: effect of reserpine. Neurosci Lett 124:119-121.

Hayakawa Y, Obata K, Itoh N, Yanaihara N, Okamoto H (1984) Cyclic AMP regulation of pro-vasoactive intestinal polypeptide/PHM27 synthesis in human neuroblastoma cells. J Biol Chem 259:92079211.

Hefti F, Gnahn H, Schwab ME, Thoenen H (1982) Induction of tyrosine hydroxylase by nerve growth factor and by elevated $\mathrm{K}^{+}$concentrations in cultures of dissociated sympathetic neurons. J Neurosci 2:1554-1566.

Helke CJ, Hill KM (1988) Immunohistochemical study of neuropeptides in vagal and glossopharyngeal afferent neurons in the rat. Neuroscience 26:539-551.

Hendry IA (1976) Effects of axotomy on the trans-synaptic regulation of enzyme activity in adult rat superior cervical ganglia. Brain Res 107:105-1 16.

Hendry IA, Iversen LL, Black IB (1973) A comparison of the neural regulation of tyrosine hydroxylase activity in sympathetic ganglia of adult mice and rats. J Neurochem 20:1683-1689.

Hokfelt T, Elfvin L-G, Schultzberg M, Fuxe K, Said SI, Mutt V, Goldstein $M$ (1977a) Immunohistochemical evidence of vasoactive intestinal polypeptide-containing neurons and nerve fibers in sympathetic ganglia. Neuroscience 2:885-896.

Hokfelt T, Elfvin L-G, Schultzberg M, Goldstcin M, Nilsson G (1977b) On the occurrence of substance P-containing fibers in sympathetic ganglia: immunohistochemical evidence. Brain Res 132:29-41.

Hokfelt T, Johansson O, Ljungdahl A, Lundberg JM, Schultzberg M (1980) Peptidergic neurones. Nature 284:515-521.
Hyatt-Sachs H, Bcinfeld MC, Baldwin C, Zigmond RE (1990) Vasoactive intestinal peptide (VIP) in the normal and decentralized superior cervical ganglion (SCG). Soc Neurosci Abstr 16:1029.

Hyatt-Sachs H, McKeon TW, Schreiber R, Piszczkiewicz S, Sun Y, Bachoo MR, Zigmond RE (1991) Effects of decentralization and axotomy on vasoactive intestinal peptide (VIP)- and neuropeptide $Y$ (NPY)-like immunoreactivity (IR) in the superior cervical ganglion (SCG). Soc Neurosci Abstr 17:400.

Ip NY, Baldwin C, Zigmond RE (1985) Regulation of the concentration of adenosine $3^{\prime} 5^{\prime}$-cyclic monophosphate and the activity of tyrosine hydroxylase in the rat superior cervical ganglion by three neuropeptides of the secretin family. J Neurosci 5:1947-1954.

Jarvi R, Helen P, Pelto-Huikko M, Hervonen A (1986) Neuropeptide Y (NPY)-like immunoreactivity in rat sympathetic neurons and small granulc-containing cclls. Neurosci Lett 67:223-227.

Johnson MI, Ross CD, Bunge RP (1980) Morphological and biochemical studies on the development of cholinergic properties in cultured sympathetic neurons. J Cell Biol 84:692-704.

Jonakait GM, Schotland S (1990) Conditioned medium from activated splenocytes increases substance $P$ in sympathetic ganglia. $J$ Neurosci Res 26:24-30.

Jonakait GM, Schotland S, Hart RP (1990) Interleukin-1 specifically increases substance $P$ in injured sympathetic ganglia. Ann NY Acad Sci 594:222-230.

Kawatani M, Rutigliano M, de Groat WC (1985) Depolarization and muscarinic excitation induced in a sympathetic ganglion by vasoactive intestinal polypeptide. Science 229:879-881.

Kessler JA (1985a) Differential regulation of peptide and catecholamine characters in cultured sympathetic neurons. Neuroscience 15: 827-839.

Kessler JA (1985b) Parasympathetic, sympathetic, and sensory interactions in the iris: nerve growth factor regulates cholinergic ciliary ganglion innervation in vivo. J Neurosci 5:2719-2725.

Kessler JA, Black IB (1979) The role of axonal transport in the regulation of enzyme activity in sympathetic ganglia of adult rats. Brain Res 171:415-424.

Kessler JA, Black IB (1982) Regulation of substance $P$ in adult rat sympathetic ganglia. Brain Res 234:182-187.

Kessler JA, Adler JE, Bohn M, Black IB (1981) Substance P in principal sympathetic neurons: regulation by impulse activity. Science 214:335-336.

Konishi S, Okamoto T, Otsuka M (1985) Substance P as a neurotransmitter released from peripheral branches of primary afferent neurones producing slow synaptic excitation in autonomic ganglion cells. In: Substance P: metabolism and biological actions (Jordan CC, Oeheme P, eds), pp 121-136. London: Taylor and Francis.

Koo EH, Hoffman RN, Price DL (1988) Levels of neurotransmitter and cytoskeletal protein mRNAs during nerve regeneration in sympathetic ganglia. Brain Res 449:361-363.

Kuo DC, Kawatani M, de Groat WC (1988) Vasoactive intestinal polypeptide identified in the thoracic dorsal root ganglia of the cat. Brain Res 330:172-182.

Lamperti ED, Rosen KM, Villa-Komaroff L (1991) Characterization of the gene and messages for vasoactive intestinal polypeptide (VIP) in rat and mouse. Mol Brain Res 9:217-231.

Iandis SC (1990) Target regulation of neurotransmitter phenotype. Trends Neurosci 13:344-350.

Landis SC, Siegel RE, Schwab M (1988) Evidence for neurotransmitter plasticity in vivo: II. Immunocytochemical studies of rat sweat gland innervation during development. Dev Biol 126:129-140.

Leblanc GG, Trimmer BA, Landis SC (1987) Neuropeptide Y-like immunoreactivity in rat cranial parasympathetic neurons: coexistence with vasoactive intestinal peptide choline acetyltransferase. Proc Natl Acad Sci USA 84:3511-3515.

Leblanc G, Landis SC (1986) Development of choline acetyltransferase (CAT) in the sympathetic innervation of rat sweat glands. J Neurosci $6: 260-265$.

Lundberg JM, Hokfelt T, Schultzberg M, Uvnas-Wallenstein K, Kohler C, Said SI (1979) Occurrence of vasoactive intestinal polypeptide (VIP)-like immunoreactivity in certain cholinergic neurons of the cat: evidence from combined immunohistochemistry and acetylcholinesterase staining. Neuroscience 4:1539-1559.

Lundberg JM, Terenius L, Hokfelt T, Martling CK, Tatemoto K, Mutt V, Polak J, Bloom S, Goldstein M (1982) Neuropeptide Y (NPY)- 
like immunoreactivity in peripheral noradrenergic neurons and effects of NPY on sympathetic function. Acta Physiol Scand 116:477-480.

Mathew TC, Miller FD (1990) Increased expression of T $\alpha 1-\alpha$ tubulin mRNA during collateral and NGF-induced sprouting of sympathetic neurons. Dev Biol 141:84-92.

Matthews MR, Cuello AC (1982) Substance P-immunoreactive peripheral branches of sensory neurones innervate guinea pig sympathetic neurons. Proc Natl Acad Sci USA 79:1668-1672.

Matthews MR, Nelson VH (1975) Detachment of structurally intact nerve endings from chromatolytic neurones of the rat superior cervical ganglion during the depression of synaptic transmission induced by post-ganglionic axotomy. J Physiol (Lond) 245:91-135.

Matthews MR, Raisman G (1972) A light and electron microscopic study of the cellular response to axonal injury in the superior cervical ganglion of the rat. Proc R Soc Lond [Biol] 181:43-79.

Nagata Y, Ebisu H, Tamaru M, Fujita K, Koide T (1989) Decrease of atrial natriuretic peptide content in rat superior cervical sympathetic ganglion after denervation and axotomy. J Neurochem 52: $1570-1575$

Nawa H, Patterson PH (1990) Separation and partial characterization of neuropeptide-inducing factors in heart cell conditioned medium. Neuron 4:269-277.

Nawa H, Nakanishi S, Patterson P (1991) Recombinant cholinergic differentiation factor (leukemia inhibitory factor) regulates sympathetic neuron phenotype by alterations in the size and amounts of neuropeptide mRNAs. J Neurochem 56:2147-2150.

Nishizawa M, Hayakawa Y, Yanaihara N, Okamoto H (1985) Nucleotide sequence divergence and functional constraint in VIP precursor mRNA evolution between human and rat. FEBS Lett 183:5559.

Nja A, Purves D (1978) The effects of nerve growth factor and its antiserum on synapses in the superior cervical ganglion of the guineapig. J Physiol (Lond) 277:53-75.

Otten U, Thoenen H (1976) Modulatory role of glucocorticoids on NGF-mediated enzyme induction in organ cultures of sympathetic ganglia. Brain Res 111:438-441.

Paravicini U, Stoeckel K, Thoenen H (1975) Biological importance of retrograde axonal transport of nerve growth factor in adrenergic neurons. Brain Res 84:279-291.

Pincus DW, DiCicco-Bloom EM, Black IB (1990) Vasnactive intestinal peptide regulates mitosis, differentiation and survival of cultured sympathetic neuroblasts. Nature 343:564-567.

Purves D (1975) Functional and structural changes in mammalian sympathetic neurones following interruption of their axons. J Physiol (Lond) 252:429-463.

Raisman G, Field PM, Ostberg AJC, Iversen LL, Zigmond RE (1974) A quantitative ultrastructural and biochemical analysis of the process of reinnervation of the superior cervical ganglion in the adult rat. Brain Res 71:1-16.

Rao MS, Landis SC (1990) Identification and characterization of a cholinergic differentiation activity present in sweat gland extracts. Neuron 5:899-910.

Rao MS, Tyrrell S, Landis SC, Patterson PH (1992) Effects of ciliary neurotrophic factor (CNTF) and depolarization on neuropeptide expression in cultured sympathetic neurons. Dev Biol 150:280-293.

Raynaud B, Faucon-Biguet N, Vidal S, Mallet J, Weber MJ (1987) The use of a tyrosine hydroxylase cDN $\Lambda$ probe to study the neurotransmitter plasticity of rat sympathetic neurons in culture. Dev Biol 119:305-312.

Roach A, Adler JE, Black IB (1987) Depolarizing influences regulate preprotachykinin mRNA in sympathetic neurons. Proc Natl Acad Sci USA 84:5078-5081.

Sasek CA, Zigmond RE (1989) Localization of vasoactive intestinal peptide- and peptide histidine isoleucine amide-like immunoreactiv- ities in the rat superior cervical ganglion and its nerve trunks. J Comp Neurol 280:522-532.

Schalling M, Stieg PE, Lindquist C, Goldstein M, Hokfelt T (1989) Rapid increase in enzyme and peptide mRNA in sympathetic ganglia after electrical stimulation in humans. Proc Natl Acad Sci USA 86: $4302-4305$.

Schalling M, Franco-Cereceda A, Hemsen A, Dagerlind A, Seroogy K, Persson H, Hokfelt T, Lundberg JM (1991) Neuropeptide Y and catecholamine synthesizing enzymes and their mRNA's in rat sympathetic neurons and adrenal glands; studies on expression, synthesis and axonal transport after pharmacological and experimental manipulations using hybridization techniques and radioimmunoassay. Neuroscience 41:753-766.

Schotzinger RJ, Landis SC (1990) Acquisition of cholinergic and peptidergic properties by sympathetic innervation of rat sweat glands requires interaction with normal target. Neuron 5:91-100.

Segerson TP, Lam KSL, Cacicedo L, Minamitani N, Fink JS, Lechan RM, Reichlin S (1989) Thyroid hormone regulates vasoactive intestinal peptide (VIP) mRNA levels in the rat anterior pituitary gland. Endocrinology 125:2221-2223.

Stefanini M, De Martino C, Zamboni L (1967) Fixation of ejaculated spermatozoa for electron microscopy. Nature 216:173-174.

Sun Y, Rao MS, Zigmond RE, Landis SC (1992) A soluble factor secreted by ganglionic non-neuronal cells increases VIP levels in dissociated cell culture and explants of rat superior cervical ganglion (SCG). Soc Neurosci Abstr 18:1475.

Tatemoto K, Mutt V (1981) Isolation and characterization of the intestinal peptide porcine PHI (PHI-27), a new member of the glucagon-secretin family. Proc Natl Acad Sci USA 78:6603-6607.

Thoenen H, Otten U, Schwab M (1979) Orthograde and retrograde signals for the regulation of neuronal gene expression: the peripheral sympathetic nervous system as a model. In: The neurosciences: fourth study program (Schmitt FO, Worden FG, eds), pp 911-928. Cambridge, MA: MIT Press.

Volle RL, Patterson BA (1982) Regulation of cyclic AMP accumulation in a rat sympathetic ganglion: effects of vasoactive intestinal polypeptide. J Neurochem 39:1195-1197.

Wolinsky E, Patterson PH (1983) Tyrosine hydroxylase activity decreases with induction of cholinergic properties in cultured sympathetic neurons. J Neurosci 3:1495-1500.

Wong J, Oblinger MM (1991) NGF rescues substance P expression but not neurofilament or tubulin gene expression in axotomized sensory neurons. J Neurosci 11:543-552.

Zigmond RE (1985) Biochemical consequences of synaptic stimulation: the regulation of tyrosine hydroxylase activity by multiple transmitters. Trends Neurosci 8:63-69.

Zigmond RE, Ben Ari Y (1977) Electrical stimulation of preganglionic nerve increases tyrosine hydroxylase activity in sympathetic ganglia. Proc Natl Acad Sci USA 74:3078-3080.

Zigmond RE, Chalazonitis A (1979) Long-term effects of preganglionic nerve stimulation on tyrosine hydroxylase activity in the rat superior cervical ganglion. Brain Res 164:137-152.

Zigmond RE, Mackay AVP, Iversen LL (1974) Minimum duration of trans-synaptic stimulation required for the induction of tyrosine hydroxylase by reserpine in the rat superior cervical ganglion. J Neurochem 23:355-358.

Zigmond RE, Chalazonitis A, Joh T (1980) Preganglionic nerve stimulation increases the amount of tyrosine hydroxylase in the rat superior cervical ganglion. Neurosci Lett 20:61-65.

Zigmond RE, Hyatt-Sachs H, Baldwin C, Qu XM, Sun Y, McKeon TW, Schreiber RC, Vaidyanathan U (1992) Phenotypic plasticity in adult sympathetic neurons: changes in neuropeptide expression in organ culture. Proc Natl Acad Sci USA 89:1507-1511. 